\title{
The Produced Self: Conflicts of Depersonalization in Edith Wharton's The House of Mirth
}

\author{
Jesús Blanco Hidalga ${ }^{1}$
}

\begin{abstract}
American critic Fredric Jameson has referred to the modern centred subject as a consequence of the historical development of capitalism: both a product of and compensation for the processes of reification and fragmentation brought about by our mode of production. For the critic, realism and modernism played a fundamental part in the consolidation of modern individuality through the use of textual strategies such as point of view and free indirect discourse, which conjure up the literary illusion of a unified self. These are procedures deftly used by Edith Wharton to build our novel's central character, Lily Bart. At the same time, however, this individuality is inevitably threatened by Wharton's particular views of society, influenced by social Darwinism, and by her acute awareness of social processes of reification and commodification. This article explores the conflict between Wharton's proposal of a unified self and the reality of depersonalization reflected by the novel. Likewise, this essay examines the strategies of containment through which the novelist seeks to assuage this contradiction and compensate for the almost unbearable loss that her social views entail for the subject.
\end{abstract}

Keywords: Edith Wharton; Fredric Jameson; modern subject; Slavoj Žižek; reification

\section{[es] El yo producido: conflictos de despersonalización en The House of Mirth de Edith Wharton}

Resumen. El crítico estadounidense Fredric Jameson considera el concepto moderno de sujeto centrado como una consecuencia del desarrollo histórico del capitalismo: un producto de los procesos de reificación y desintegración inherentes a nuestro modo de producción y al mismo tiempo una compensación por los mismos. Para el crítico, realismo y modernismo jugaron un papel fundamental en la consolidación de la individualidad moderna mediante el uso de estrategias textuales como el punto de vista y el discurso libre indirecto, las cuales conjuran la ilusión literaria del yo unificado. En la novela que nos ocupa, Edith Wharton utiliza con destreza estos procedimientos para construir su protagonista, Lily Bart. Sin embargo, esta misma individualidad resulta al tiempo amenazada por la personal visión social de la autora, influida por el darwinismo social y caracterizada por una aguda consciencia de los procesos sociales de reificación y mercantilización. Este artículo explora el conflicto entre el yo unificado propuesto por Wharton en la novela y la realidad de la despersonalización reflejada por la misma. De igual modo, se examinan las estrategias de contención con las que la novelista trata de mitigar esta contradicción y compensar la casi insoportable pérdida que su visión social conlleva para el sujeto.

Palabras clave: Edith Wharton; Fredric Jameson; sujeto moderno; Slavoj Žižek; reificación.

Contents. 1. Introduction. 2. Thinking the Modern Subject: Loss and Compensation. 3. A Society of Specimens. 4. Mediated Subject. 5. Disseminated Subject. 6. Strategies of Compensation and Containment.

1 Departamento de Filologías Inglesa y Alemana, Universidad de Córdoba

ORCID: 0000-0002-6767-745X

E-mail: jblancohidalga@yahoo.es 
How to cite this article: Blanco Hidalga, J. (2019) The Produced Self: Conflicts of Depersonalization in Edith Wharton's The House of Mirth, in Complutense Journal of English Studies 27, 259-274.

\section{Introduction}

Edith Wharton's second novel, The House of Mirth (1905), is commonly accepted as a landmark of American realism right at the threshold of modernism. It is also a most interesting example of the close relationship between the novelistic genre and certain developments in the modern notion of the subject that are still with us. Perhaps the most striking manifestation of that relationship in The House of Mirth is the tension that can be perceived between, on the one hand, Wharton's reliance on a specific series of rhetorical procedures for the production of the individual subject in literature and, on the other hand, her particular vision of a social configuration, namely that of industrial capitalism, which seems to dissolve that rhetorical product. Wharton uses typically modernist literary techniques of point of view and free indirect discourse to generate the literary version of a unified subject (that of the novel's protagonist). However, at the same time, her deterministic vision of commodified subjects created by impersonal social structures, of groundless individualities disseminated over the body social, inevitably exposes that unified subject as a precarious artefact, a fiction. But this is a fiction, it must be added, which is all but indispensable for those who are to inhabit the world Wharton is out to portray. This predicament leads the novelist to deploy a series of conceptual and aesthetic strategies to manage this ambivalence and contain its darker implications.

The House of Mirth is mainly the story of the impoverished socialite Lily Bart. Lily is a creature of turn-of-the-century New York's high society. However, her father died a bankrupt and now she depends on her rich but ungenerous aunt Mrs Peniston for sustenance. Characterized by charm, beauty and exquisite manners, Lily's presence is sought and appreciated in the highest social circles, where she is to find a wealthy husband to secure her position. Lily is nearly twenty-nine years old, so she is approaching a critical age for that purpose. She manages to attract the favours of the dull but moneyed Percy Gryce, who is considered by every character around as a highly desirable match, but the young man is eventually driven away as her inconvenient friendship with lawyer Lawrence Selden becomes evident. Since the beginning of the novel, it is obvious that Lily and Selden are two kindred spirits that should be together, but this is prevented by the latter's lack of means to afford Lily her desired social place and by his inflexible and somewhat hypocritical moral professions. Lily' allowance is not enough to maintain her necessary social presence (which includes gambling in social gatherings), so she incurs in debts with the wealthy Gus Trenor. The man expects Lily's sexual favours in exchange of his financial aid, so he deceives her into coming to his house where he is alone. Lily barely escapes being raped by Trenor but she is seen coming out of his house alone. Her social rivals, most notably her relentless enemy Bertha Dorset, use this and other incidents to set in motion a chain of rumours and slander against Lily. This culminates with her expulsion from the Dorsets' yacht during a tour of Europe, after Bertha publicly accuses Lily of having an affair with her husband. The ensuing scandal ruins Lily's possibilities of receiving a marriage proposal. Much to Lily's sorrow, even Selden comes to accept the general disparaging opinion of her. In a cruel turn of destiny, she comes across 
a bunch of love letters addressed by Bertha Dorset to Selden. If made public, these letters would mean Lily's salvation from discredit. However, considering the possibility that their circulation could entail harm for the lawyer, Lily destroys them. All the efforts to prove her integrity and clear her name are in vain, and Lily inexorably goes down the social scale, but not without rejecting a marriage offer by the rich Jew $\mathrm{Mr}$ Rosedale that would have meant her material salvation. Eventually she has to take up an undignified job at a hat workshop. By then she has acquired an addiction to chloral that will lead to her death by overdose in loneliness and destitution.

\section{Thinking the Modern Subject: Loss and Compensation}

The main theoretical grounding of my approach to The House of Mirth is Fredric Jameson's conception of the modern subject as a historical construction in whose shaping and consolidation the novelistic genre played a fundamental part. More specifically, I draw on Jameson's view of what he calls, after Lacan, the modern centred subject - the bourgeois ideology of the psychic unity of the subject - as both the product of and a compensation for the generalized reification brought by the global triumph of capitalism. Jameson is certainly not alone in highlighting the essential role of the novel in the development of the modern subject. For example, Nancy Armstrong makes the strong claim that the history of the novel and the history of the modern individual are "one and the same" (Armstrong 2005: 3), as she credits the English novel with the formulation of a modern subjectivity that was subsequently reproduced in British and eventually Western culture. However, Jameson's view stands out in the way he dialectically relates the constitution of the modern subject to successive modifications in the mode of production, identifying in the process of such construction diverse compensational functions that aim to redress different types of loss entailed for the individual subject in socio-economic development.

Before addressing the relationship between subjectivity and mode of production, a brief clarification of the key concept of reification as used by Jameson is pertinent. Max Weber's notion of rationalization, was re-elaborated later by Georg Lukács as reification, to refer to an inherent dynamics of capitalism consisting in the systematic breaking up of "natural" unities - including all sort of social and cultural forms - into independent smaller parts which are later reconstructed in new "post-natural" processes so as to achieve a more efficient management. This process of secularization of cultural forms and institutions brings about a permanent suspension of ends and ultimately amounts to a complete instrumentalization of the world (see Jameson 2002 [1981]: 48). For Jameson, this dynamic has a correlate in artistic periodization: what are often regarded as incompatible modes of representation, such as realism, modernism, or postmodernism, actually correspond to subsequent stages of the same general secularizing dialectics of reification. This is an ever-intensifying process that affects institutions and subjectivities when their social and ideological preconditions have been substantially altered by economic development, eroding their hierarchical or sacred content. The threat that a reified environment, marked by the relentless contingency and mutability brought by socio-economic change, poses for any notion of functional subjectivity is obvious. However, the new, changing world of industrial capitalism requires stable, functional subjects probably to a greater degree than any previous social organization. A way out of this contradiction is afforded by the symbolic power 
of narrative. As Jameson argues in The Political Unconscious, all narrative can be interpreted as the symbolic resolution of unsolvable social contradictions. This means that realism and modernism brought with them their own compensation for the same pressure of reification that was responsible for their appearance in the first place. For Jameson, in the new capitalist environment that emerges in the nineteenth century, in which older "organic" social groups are dissolved and individuals reduced to commodified, isolated and equivalent units in the anomie of the labour-power market, the creation of what Lacan called the centred subject, that is, "the protective development of a monadic armature, ... comes as something of a compensation" (Jameson 2002 [1981]: 140). Indeed, for Jameson, the consolidation of the centred subject constitutes not only a compensation for psychological loss, but also an instance of the ways in which the genre of the novel "reprograms" its readers for life under capitalism by enabling them to deal with a world characterized by disjointedness and fragmentation (2002 [1981]: 138). This new subjectivity of the bourgeois monadic individual is institutionalized in a series of narrative devices that become prominent in high realism and which Jameson refers to as "textual determinants". It is the case of Balzac's omniscient narrator, Flaubert's free indirect speech or Henry James's point of view; three techniques that may be combined to conjure the most vivid image of a unified self that could be conceived of. This is exactly what Wharton seems intent on, as she shows us the world of turn-of-the-century New York's aristocracy through the experience of the novel's central character and deftly uses free indirect speech to make Lily, so to speak, think herself into existence. In fact, the question of Lily's individuality is the cornerstone of the novel. As Joan Lidoff realizes, The House of Mirth can be regarded as a romance of identity. Indeed, Lily's vicissitudes as she tries to assert her own story against society's views are nothing short of a quest for identity. In Lidoff's words, "Wharton encourages reading her novel of social realism as romance. Lily's allegorical progress from house to house down the social scale invites us to read in romance's allegorizing, abstracting mode" (Lidoff 2003: 183).

My point is that the textual strategies mentioned above are insufficient for the task of conforming Lily's individuality as a centred subject, not only due to their own inescapable limitations but also by virtue of Wharton's distinctive view of society. As I have advanced, The House of Mirth is run through by a conspicuous tension: that between Wharton's need for self-centred subjectivity (which is also, we should remember, her readers' need) and her own awareness of the reality of reification and commodification; a strain which can be seen as a sort of unacknowledged resistance to her own deeper intuitions. I shall be especially concerned with the strategies of containment through which the novelist seeks to symbolically make up for this contradiction and compensate the reader for the bleak vision of the individual as a mere product of deterministic and alienating social forces that is conveyed by the novel. In this analysis, I will rely in Slavoj Žižek's theory of ideology.

\section{A Society of Specimens}

One feature that makes The House of Mirth stand out among contemporary examples of proto-modernist fiction is surely Wharton's striking social outlook. To begin with, Wharton is characterized by a remarkably comprehensive social awareness that goes beyond the higher-class circle focused by the novel. It is revealing of the depth of 
Wharton's social vision that the glitter of the high society she describes is regularly shown to rest on an obscure "nether side" (Wharton 1996: 109) of exploited human labour. For example, Selden reflects on contemplating Lily that "she must have cost a great deal to make, that a great many dull and ugly people must, in some mysterious way, have been sacrificed to produce her" (1996: 5). Lily, on her part, "had always accepted with philosophic calm the fact that such existences as hers were pedestalled on foundations of obscure humanity" (159). Perhaps most significant of all, the novel actually shows us a picture of working-class life as Lily ends up earning her living in the hardship of the workshop.

However, this wider scope in terms of class is only a part of Wharton's particular vision of society. There is also the influence exerted upon her thought by Darwinist ideas and particularly by the work of the British philosopher Herbert Spencer (18201903), one of the founders of social Darwinism. In this way, the New York high society portrayed in The House of Mirth is a sort of ecosystem, described with profusion of biological and environmental metaphors, populated by specialized creatures whose vital aim is to blindly perform the specific social function for which they have been produced by impersonal social structures. In the case of Lily, her function is to decorate social gatherings with her beauty and charm, and eventually marry a rich husband and thus help perpetuate their breed:

Inherited tendencies had combined with early training to make her the highly specialized product she was; an organism as helpless out of her narrow range as the sea-anemone torn from the rock. She had been fashioned to adorn and delight; to what other end does nature round the rose-leaf and paint the humming-bird's breast? (316)

Although The House of Mirth is the most ostensibly concerned with social Darwinism among Wharton's novels, these ideas are recurrent in her fiction. For example, in The Age of Innocence (1920), another novel where Wharton analyses the workings of New York's high society, the protagonist Newland Archer looks at his fiancée May Welland and wonders "how many generations of the women who had gone to her making had descended bandaged to the family vault?" (Wharton 1996: 905) Likewise, he remembers "some of the new ideas in his scientific books and the much cited instance of the Kentucky cave-fish" (1996: 905). In The Age of Innocence the angle of Wharton's analysis of the relationship between society and the individual shifts somewhat towards the effect of social conventions on personal happiness, but there are also explicit descriptions of individuality as a social product: May appears to Newland as "the terrifying product of the social system he belonged to and believed in" (1996: 873). It is hardly surprising then that these depersonalising views of society should work to undo any rhetorical work aimed at the construction of a unitary individual. Indeed, no omniscient narrator can produce a unified subjectivity as strong as to resist the kind of reification and commodification Lily Bart is put through in The House of Mirth.

\section{Mediated Subject}

The inexorable character of the individual's configuration by external forces is frequently emphasized in the novel. The narrating voice insists on the fact that Lily's 
education prevents her from imagining a different type of life for her (236). Lily's raising and circumstances have turned her into an exquisite social "ornament" (122): "it was the life she had been made for: every dawning tendency in her had been carefully directed toward it. She was like some rare flower grown for exhibition" (334). This kind of determinism, set against Lily's will to assert her individuality and abide by her own moral and affective inclinations is what produces the tragic horizon of the novel, the unforgiving fate that will ultimately crush its protagonist. The novel invites us time and again to see Lily as a mere specimen who eventually becomes a true individual by means of heroic abnegation and tragic commitment to her own moral views. Her tragic end brings its own consolation, as we will see, drawing on the dignity endowed by heroic defeat to ultimately consecrate Lily's individuality. Lily shall lose the battle against her destiny (which is, of course, a battle against society), but in the process she will attain a kind of sublimity that acts as compensation and as a vindication of the individual. In any case, it is more productive to transcend the more superficial hermeneutical framework of social Darwinism, an ideological construction that after all constitutes in the first place a justification of the competitive drive of capitalism by means of its naturalization. If we apply in our analysis the categories of reification and commodification (understanding the latter as a consequence of the former, and both as processes inherent to the dynamics of capitalism), deeper instabilities in the constitution of the subject are brought to light, together with the strategies of containment that they elicit on the novelist's part.

Commodification is a complex notion but, for my purpose here, it may be succinctly defined as the phenomenon, typical of capitalist societies, whereby all sorts of objects, people and their relationships, social and cultural institutions, are conceptualized as if they were objects of trade. In the New York high society depicted by the novel, Lily's role is essentially that of a commodity. Lily's lack of means forces her to exchange her charm and beauty for luxurious maintenance at elegant social meetings, until she can consummate the ultimate transaction of giving herself to a rich husband in return for definitive social privilege. Commodification is a central issue in The House of mirth, a novel that untiringly illustrates the different ways in which the logic of the marketplace controls social interaction. Wai Chee Dimock (2003) has studied how virtually all social intercourse in the novel is described in business-like terms. As she shows, some characters, such as Trenor or Rosedale, most openly voice the language of the marketplace, but even a supposed higher spirit such as Selden is driven by a tacit transactional logic as he weighs the pros and cons of a possible romance with Lily. Besides, although the society shown by the novel is clearly patriarchal, it is not only women that are commodified: rich husbands and marriage candidates are also assessed in terms of material value. Lily herself does so when she examines the qualities of Mr Gryce as a prospective husband. The language of business exchange permeates the novel with ironic purposes, though it is so ubiquitous that at times, as Lidoff has noticed, it becomes unclear whether Wharton "is controlling, rather than controlled by, the substitution" (Lidoff 2003: 191).

For the enjoyment of such a desirable creature as Lily, be it temporary, as in the case of wealthy hosts, or permanent, as in the case of prospective husbands, people are willing to spend money. This means that, like any marketable commodity, Lily has an assigned value that is subject to valuation or depreciation, according to other people's appreciations. From the very beginning, Lily is presented as an object of 
other people's speculation as to her motives: "it was characteristic of her that she always roused speculation" (3). But the other sense of the term speculation, the one related to the fluctuations in the putative value of a commodity is inevitably also brought to bear. In fact, the issues of commodity fetishism and speculation are emphasized in the novel by the presence of motifs such as the Americana (collectible vintage objects representative of American culture) cherished by the affluent $\mathrm{Mr}$ Gryce, the comforting value stability of jewellery, or its reverse: the mutability of the stock-exchange market. In very much the same way, for the upstart Mr Rosedale Lily appears at first as a sound investment in his scheme for social advancement, but after her fall of social grace he finds her appealing merely as a collector's item: "It was her very manner of holding herself aloof that appealed to his collector's passion for the rare and unattainable" (119). As the narrator recounts, dealing with Rosedale makes Lily feel like "no more than a super-fine human merchandise" (268). The more disturbing sexual implications involved in Lily's commodified status are not spared in the novel, as her harassment by the deceptive Mr Trenor illustrates. After spending money on Lily, the wealthy man expects to make use of her:

He knew only that he had never seen Lily look smarter in her life, that there wasn't a woman in the house who showed off good clothes as she did, and that hitherto he, to whom she owed the opportunity of making this display, had reaped no return beyond that of gazing at her in company with several hundred other pairs of eyes.

This commodification inevitably means that, much as she strives, Lily's individuality will never be self-centred, but will always be compromised by the mediation of other people's calculations. Wharton makes clear that Lily resents this situation as contrary to her struggle to achieve a self-centred individuality:

When she ceased to amuse Judy Trenor and her friends she would have to fall back on amusing Mrs. Peniston; whichever way she looked she saw only a future of servitude to the whims of others, never the possibility of asserting her own eager individuality. (106)

All this entails that a fundamental part of her being will always be alienated, that is, in possession of others. After all, turning anything into an object of speculation entails bracketing its real value and submitting it to an unpredictable and potentially unending chain of alien appreciations. Identity, the novel implies, is a (quantifiable) social matter, and thus we will never be in full possession of it: when Lily is faced with the possibility of "social death," she realizes "how completely she had been a creature of its [society's] favour" (275). We are reminded here of Emile Benveniste's (1974) view of identity as performative, as Lily tries hard to assert her own vision of herself as a virtuous girl. However, as J.L. Austin (1975) theorized and the novel compellingly reflects, a performative speech act is by definition a social act implying two unavoidable elements: a recognised sender and acquiescent receivers - $\mathrm{a}$ felicitous state of affairs which is denied to Lily by New York's high society. With these intuitions, Wharton anticipates the concern with the mediation of other people in the constitution of our own identity that will become a major issue in Woolf's novels, especially in The Waves (1931). 


\section{Disseminated Subject}

With these considerations we may notice that we are moving beyond commodification and beyond what Marx and Engels referred to as the "cash nexus," or the chrematistic bond that keeps society together under capitalism (Marx and Engels 2010: 23). Now we are dealing with deeper forces of de-personalization that undo the unitary subject which Wharton is trying to put together in the novel-forces which are inherent to Lily's symbolic function. As Margot Norris has pointed out, in the novel Lily is portrayed as a sign: "The house of mirth focuses attention specifically on how novels use the figure of woman as a carrier or code of value - that is, as a sign." (Norris 1994: 433) Fundamental and omnipresent as it is, money is not everything in Lily's social ecosystem. Although the novel informs us that the "social credit" of Lily's nemesis, Bertha Dorset, "was based on an impregnable bank account" (274), wealth is not the only source of legitimation in its world. The elusive concept of distinction, that way of marking social differences by means of habits of consumption and demeanour which was comprehensively studied by Pierre Bourdieu (1984), is also essential. In fact, the most prestigious layers of New York's society use distinction as a protection against the threatening arrival of unpolished, upstart money to their sphere, which they experience as a process whereby true aristocracy is replaced by the increasing power of commerce. Distinction then becomes a sort of compensation for what Ulrich Beck (1992) calls the de-feudalization of modern society, which is after all just another aspect of the general process of reification brought by capitalism. This takes us to the distinguishing function performed by ornamental figures such as the young gentleman Ned Silverton or Lily herself. Members of the higher class, especially those who seek to be accepted into its most fashionable ranks, are willing to pay to be seen with them because they are tokens of social acceptancebecause of what they symbolize within a specific social code. Now to be a living symbol may entail tangible material advantages but also carries important problems when it comes to keep a self-centred, unitary self, as it is obvious that a symbol has meaning or use only by virtue of an external social agreement. Being a symbol, like the proverbial Bakhtinean linguistic sign, means to be overpopulated with the intentions of others. Indeed, taking into account that, according to Charles Sanders Peirce's classic semiotic classification, the linguistic sign is a symbol (as opposed to other types of signs such as indexes and icons) it is tempting to draw a parallelism between Lily's symbolic status in the novel's semiotic system and that predicated by Derrida of the linguistic sign. As the French philosopher taught us taking Saussure's tenets to their logical (in)conclusion, language is not a collection of individual meaningful units but a system of differences. If meaning is produced by an unending play of differences, meaning is, so to speak, disseminated along the system of signifiers. This entails that to mean is automatically not to be. In the same way, in spite of all her striving for self-presence, Lily's identity is disseminated, in the Derridean sense of the term, all over the society that has generated her and granted her symbolic value. This becomes clear in the way Selden's view of Lily is always tinged by other people's judgement of her: "How could he lift Lily to a freer vision of life, if his own view of her was to be coloured by any mind in which he saw her reflected?" (168) Lily's image is then diffracted and disseminated by her reflection in the mirrors of other people's minds. Mirrors or, in Latin, specula: again, we are confronted with a sort of speculation. Lacan refers to traditional conceptions of the subject as 'subject 
of the signified', that is, an active agent that carries its own meaning-a subject, in sum, which expresses itself in language. Against this notion, the character of Lily illustrates that, as Žižek argues from his Lacanian perspective, "symbolic representation always distorts the subject, that there is always a displacement, a failure - that the subject cannot find a signifier which would be 'his own', that he is always saying ... something other than what he wanted or intended to say" (Žižek 1989: 198).

The social dissemination of identity is highlighted in the novel by a crucial thematic element that can also be conceived as a kind of speculation, namely gossip. As the characters in the novel are well aware of, being talked about endangers our socially mediated self. In a way, it may steal our socially constructed being from us much in the way the proverbial savage fears that being photographed will deprive her of her soul. Lily experiences the destructive power of gossip when malicious rumours about her virtue undermine her social stand and ultimately ruin her. It is no wonder that the novel relates gossip with contamination and contagion:

It was horrible of a young girl to let herself be talked about; however unfounded the charges against her, she must be to blame for their having been made. Mrs. Peniston felt as if there had been a contagious illness in the house, and she was doomed to sit shivering among her contaminated furniture. (133)

There is a sense in which the fear of gossip which pervades the novel recalls the distrust of writing expressed by Plato in his Phaedrus, especially as it was interpreted by Derrida in Dissemination (1981). Because what is gossip but a representation of the uncontrollable processes of difference and absence that distort and corrupt the text (her virtuous being) that Lily is desperately trying to produce about herself? In keeping with this, we may remember, from a different but not unrelated point of view, that for Heidegger the subject of gossip or "idle talk" (Gerede) is also affected by an ontological loss, a sort of bracketing and a suspension of self-presence:

Idle talk, which closes off in the way we described, is the mode of being of the uprooted understanding of Da-sein. However, it does not occur as the objectively present condition of something objectively present, but it is existentially uprooted. Ontologically, this means that when Da-sein maintains itself in idle talk it is - as being in the world - cut off from the primary and primordially genuine relations of being toward the world, toward Mitda-sein, toward being in itself. (Heidegger 1996: 159)

Accordingly, spreading rumours are presented in The House of Mirth as a menacing proliferation of groundlessness. This takes us to a dread that runs through the novel with varying degrees of implicitness: a disquieting sense of a void, or meaninglessness, at the heart of social life, an awareness of its lack of any actual substance. In her final revelation, Lily comes to realize that "there had never been a time when she had had any real relation to life" (336). Here we may wonder what kind of real relation could have been possible at all in the novel's world. Just as it happens with Lily's commodification, the evanescence of her identity also affects the other characters. A close look at the novel's secondary characters reveals them surprisingly abstract, in consonance with the allegorical and romance-like characteristics of the novel mentioned above. From Lidoff's psychoanalytic perspective, "[s]ilent spaces between 
characters remain unbridgeable because the characters themselves are the simplistic projections of unintegrated fragments of personality" (Lidoff 2003: 184). Even her arch-rival Bertha Dorset seems a mere projection of Lily's unconscious desire for revenge. As Lidoff puts it, Bertha is no more than "the feminine figure of projected evil in romances of male development" (Lidoff 2003: 200).

In addition, social life as portrayed in The House of Mirth seems a disembodied game made of empty rituals and banal codes. A game, in short, of signifiers. This kind of groundlessness is symbolized in the novel in the tableaux vivant show at the Wellington Bry's ball, where Lily impersonates the lady in Sir Joshua Reynolds's picture Mrs Lloyd, a lady who is in turn impersonating a classical dryad. As Margot Norris argues, the ball becomes "a mise en abyme, or infinite regress of representation without a fixed origin or point of value" (Norris 1994: 439). Once again, we find a metaphorical play of mirrors. Although it is in The House of Mirth where the sense of meaninglessness and lack of substance is most pronounced, it is very precisely spelled out in The Age of Innocence: "In reality they all lived in a kind of hieroglyphic world, where the real thing was never said or done or even thought, but only represented by a set of arbitrary signs" (874). At this point, using Lacan's concepts again, one may well speculate about the Real of this symbolic realm which is New York's high society as presented by Wharton; about the irreducible core of raw life resistant to symbolization that underlies its rituals and codes. If the reality of exploitation, greed and lust at the foundations of social life are perhaps too obvious answers, then it is suggestive to point again at the void at its heart, at the meaninglessness that a frantic profusion of stylized games desperately tries to conceal.

\section{Strategies of Compensation and Containment}

We have seen that Wharton's vision of society as a system of impersonal structures produces a mediated, disseminated subject devoid of substance. However, there are ways in which the almost unbearable instability of the subject implied by Wharton's vision of society is mitigated in the novel-ways, in short, that afford the reader a compensation for an otherwise dismal perspective. These moves involve a measure of social and individual hope, the aesthetic pleasure of tragedy and, above all, an appeal to sublimity. As we will see, Wharton presents sublimity-incarnated in the tragedy of Lily's heroic battle with society, her selfless regard for Selden's safety, and eventually her death - as a compensation for an intimate experience of loss of identity and social substance that is bound to be shared by both writer and reader. That this means for the novelist to incur in contradiction with her darker intuitions about society and the individual as presented by her novel needs not surprise us. As Franco Moretti holds, the novel is a symbolic artefact that tends to the assuagement of social and psychological conflicts, particularly those arising from the individual's need for self-determination and the commanding demands of socialization. For the Italian critic, the literary pleasure readers derive from a novel lies greatly in the genre's capacity to reduce and bind "the tensions and disequilibrium of everyday experience". In his words, "[w] hat makes literature symbolically necessary is precisely its capacity to mediate and compromise- to teach us how to 'live with' disturbing phenomena." (Moretti 1987: 160) In the case of our novel, we find the further ambivalence that these forms of compensation can also be read 
as so many ways of exerting resistance against the pressing forces of reification and commodification.

One of these forms of compensation, of a symbolic character, lies in a brief and quite unexpected vision of community witnessed by Lily at the end of her social downfall. Nettie Struthers, a former fellow worker at the hat workshop, finds the despondent Lily in the street and amiably takes her to her humble dwelling. A sort of Dickensian sentimentality characterizes the passage. It is the only manifestation of true solidarity Lily is offered in the whole novel. The scene, in which the warm-hearted Nettie lets Lily hold her baby, provides a striking contrast with the social milieus previously shown in the novel. Not only the selfishness but also the barrenness of the high society (children are absent from Wharton's depiction of it) are underscored by these images of fertility and solidarity within the working class. As Elaine Showalter points out, the scene expresses Lily's "hunger for physical bonding" (Showalter 2003: 55). Certainly, For Lily, never inclined to question the society that has produced her, the moment brings forth a revelation. She recognizes her rootlessness, her lack of attachment to anything substantial, to humanity at large. Now she realizes the "solidarity of life". As the narrator puts it, previously Lily's sense of community "had been checked by the disintegrating influences of the life about her. All the men and women she knew were like atoms whirling away from each other in some wild centrifugal dance: her first glimpse of the continuity of life had come to her that evening in Nettie Struther's kitchen" (337, my emphasis).

These lines are invested with the most tangible hint of social hope that can be found in the novel, as Wharton seems to find in the working class a measure of transcendence and an alternative to society's pervading commodification. However, this attempt is problematic and inconsistent, mostly because Wharton herself seems unconvinced about it. In Nettie's scene Wharton strikingly suspends the irony that characterizes her outlook throughout the novel, and Nettie is obviously romanticized. As Wai Chee Dimock puts it, “[a] 'naturalized' working class represents Wharton's best hope for an organic life beyond the marketplace" (Dimock 2003: 81). Nevertheless, as the critic explains, "[o]n a number of occasions - most particularly when Nettie expresses her innocent hope that her daughter ('Marry Anto'nette') will grow up to be just like Lily - we see the corrosive vision of the ironist subverting the 'alternative' she has so painstakingly set up" (Dimock 2003: 81). In any case, the importance of the scene at Nettie's kitchen is underscored by its moving echo at the end of the novel, when Lily holds the baby again in her deathbed hallucination. Again, there is a fundamental ambiguity in that episode. As Elaine Showalter has noticed, this ambivalence has allowed feminist critics such as Patricia M. Spacks or Cynthia Griffin Wolff to describe the passage as a sentimental move of escapism into infantilization, while others like Showalter herself see it as showing "Lily's awakened sense of loving solidarity and community" (Showalter 2003: 55).

Then there is what we may call a rhetoric-cognitive kind of compensation, an implicit redress of de-individualizing forces in The House of Mirth. If the self, as Wharton seems to feel, is inevitably compromised because its constitution in social interaction leads to its commodification and alienation, one solution lies in imagining a sort of dual self. This subjectivity would be composed of an outer self, always involved in the perils of social interaction, and an inner self: a semi-autonomous metaphysical realm where self-presence can be attained. Of course, this concept is far from new. As Žižek argues, "we could say that the principal illusion of the En- 
lightenment consists in the idea that we can preserve a simple distance from the external 'machine' of social customs and thus keep the space of our inner reflection spotless, unblemished by the externality of customs." (Žižek 1989: 88) Although, as the novel shows, this inner self is also bound to be unstable, it has a crucial importance as it legitimizes the claim of a true self of one's own.

The proposition of a dual self is instantiated in the novel by recurrent spatial metaphors that propose a twofold subject. This figure of speech is consistent with what, in his analysis of confessional discourse, Peter Brooks calls the "metaphor of depth", a trope that accompanies the emergence of the modern sense of self in Western culture (Brooks 2000: 102). It may also be seen as an example of what Lakoff and Turner (1980) defined as a cognitive metaphor, that is, one of the many tropes that structure our perceptual and conceptual system. In any case, the metaphor of a dual self is elevated by Wharton to a central pillar of the novel's discourse, to a kind of existential alibi. This spatial duality is asserted time after time through the novel to define Lily's and Selden's subjectivities. In this way, for example, to emphasize the authenticity of Lily and Selden's relationship, the narrator claims that "an indwelling voice in each called to the other across unsounded depths of feeling" (75). What is more, in the novel Selden brings Lily's real self out of the usual depths where it dwells: "this real self of hers, which he had the faculty of drawing out of the depths, was so little accustomed to go alone!" (99). The duality of Lily's self, composed of her true inner self and the outer one corrupted by social interaction is made explicit by Wharton: "She seemed a stranger to herself, or rather there were two selves in her, the one she had always known, and a new abhorrent being to which it found itself chained" (156). The list of examples could certainly run for longer. Let us just observe a final one where the inner self is once again asserted as the true self: "the sense of loneliness returned with redoubled force as she saw herself shut out from Selden's inmost self' (323). It is interesting to notice that a similar spatial metaphor is already used to describe a woman's self in "The Fulness of Life" (1891), one of Wharton's early short stories. Here, the true self or "soul" is located in a secluded "innermost room" independent of social intercourse:

I have always thought that a woman's nature is like a house full of rooms: there is the hall, through which everyone passes in going in and out; the drawing room, where one receives formal visits; the sitting room, where the members of the family come and go as they list; but beyond that, far beyond, are other rooms, the handles of whose doors are perhaps never turned; no one knows the way to them, no one knows wither they lead; and in the innermost room, the holy of holies, the soul sits alone and wait for a step that never comes. (Wharton 2001: 14)

Ultimately, these metaphors convey the stabilizing assumption that the subject is some kind of interior, transcendental meaning that exceeds its symbolic articulation, that cannot be put properly into words. From a Lacanian point of view, however, the explanation would be the opposite: the subject of the signifier is precisely that lack, this failure of representation.

Finally, the most effective way in which the novel mitigates the horrors of determinism and depersonalization that characterize the world it portrays, is probably a kind of discursive-ideological compensation that may be characterized as the achievement of transcendence through sublimity. We may grasp this process when 
we examine the striking way in which Lily refuses, time after time, to perform the actions that would save her in their fall. As Dimock has noticed, Lily's rebellion against society takes the form of "playing by the rules", an absurd and ultimately self-defeating "rebellion by submission" (Dimock 2003: 73-74). In her psychoanalytical reading of the novel, Lidoff interprets that Lily's refusal to take effective action to defend herself functions to obscure her own unacknowledged desires for revenge while maintaining a self-image of purity, even at the cost of her life. (Lidoff, 2003: 198) This is a plausible explanation, and it is certainly related to the lack of discursive means or channels for effective self-assertion available to women at the time. As Lidoff states, "when society provides no adult female role of active responsibility and initiative, women are confined to passive and childlike states and cannot mature" (Lidoff, 2003: 202). This, in a way, makes Lily's death inevitable in the narrative. In Lidoff's words: "Lily has to die because she cannot live. A grown and beautiful woman, she can no longer exist as a child, but neither can she become an adult." (Lidoff, 2003: 203)

However, there is another way of assessing Lily's sterile sacrifice: as another attempt at articulating a subject position through existing discursive constraints. I have already advanced this way: Lily's tragic death constitutes an aesthetic vindication of the individual. The tragic character of Lily's end is in great part determined by the heroic manner in which she refuses any easy way outs of her predicament. When her morality is fatally questioned by rumours, she aims to show society that it has been wrong about her and she wants to show it in society's own terms (which are, after all, also her own). Crucially, in that purpose she renounces any possibility that implies being untrue to herself and her moral code, most significantly marrying Mr Rosedale and publishing the incriminating letters that would endanger Selden. It is true that, as Mary Nyquist has argued, Lily's ethical principles are ultimately aesthetical and "highly conventional" at that. In Nyquist's words, the novel "doesn't ever suggest that ethical principles are categorically distinct from the essentially aesthetic form taken by her scruples" (Nyquist 2001: 96); but, for all the conventionality, this agonic struggle against society is the force that substantiates Lily's individuality against the depersonalizing environment that has created her.

The fact that the individualizing process chosen for Lily's character can be described as a display of abnegation is significant. Her principles may be conventional and similar to scruples, but she is willing to submit to all hardships rather than renounce them, which confers a strange dignity on her decision. According to Armstrong, abnegation is the defining characteristic of some of the most representative heroines of Victorian fiction. As the critic has argued apropos of Jane Eyre, "such self-discipline empowered her to tell a story in which she alone set the standard for moral judgment and social behavior" (Armstrong 2005: 79). In fact, we may even see this stand as a way of achieving effective subjectivity by embracing the injunctions of an ultimately irrational — and as such impregnable - categorical imperative that resists and opposes external social pressures. At this point, we cannot forget that, following Lacan, there is an obscene element of enjoyment in the moral imperative behind acts of sacrifice and renunciation: the giving up of enjoyment itself produces a "surplus-enjoyment". As Žižek points out, "this Kantian moral imperative conceals an obscene superego injunction: Enjoy! - the voice of the Other impelling us to follow our duty for the sake of duty is a traumatic irruption of an appeal to an impossible jouissance" (Žižek 1989: 88-89). 
In any case, Wharton invests Lily's individualizing abnegation with the robes of the sublime when she makes her self-denyingly renounce her beloved Selden for his own sake. She turns Lily into something of a saint: not only does Lily burn the letters that could save her, but she does it while she keeps Selden in ignorance of her possession of them, just to spare him the burden of knowledge. Here we understand the Sublime in the light of Žižek's interpretation of the Kantian formulation in The Critique of Judgement: Kant's notion of the Sublime comprises two moments in the experience of the subject. In the first place, there is a failure, a painful realization of the limitations of the subject, of the inadequacy of its perceptual capacities confronted to the Sublime; but by virtue of this failure, we experience the limits of the human faculty of reason and thus get an intuition of the true dimension of the sublime object. This rhetorical strategy can perform an important ideological role in protecting the subject and we may actually observe it at work in Wharton's handling of Lily's tragedy, which she uses to compensate for her failure at conforming a self-centred subjectivity for her character. In fact, it is precisely because of her commanding depiction of the ways in which the subject is mediated in its constitution by social and symbolic structures that Wharton has to aim at the Sublime. As Žižek argues following Hegel and Lacan, if the subject turns out to be ultimately a void, the Sublime is what takes its place. In his words, the Sublime becomes "an object which occupies the place, replaces, fills out the empty place of the Thing as the void, as the pure Nothing of absolute negativity - the Sublime is an object whose positive body is just an embodiment of Nothing" (Žižek, 1989: 234). In the same way, Lily's subject becomes a sublime object that takes the space of a void. This certainly entails a conception of the subject as a sort of ideological misrecognition, but also shows it as a necessary one.

Eventually, the truth about Lily will remain unknown in society. Paradoxically, from a Lacanian perspective, we may notice that Lily's failure in articulating her own story is the way she retrospectively becomes a subject in the realm described by Žižek as the Sublime. To use the philosopher's words, "The subject tries to articulate herself in a signifying representation; the representation fails; instead of a richness [of meaning] we have a lack, and this void opened by the failure $i$ s the subject of the signifier." (Žižek 1986: 198) This has a compensational effect that is extended by means of the elevation into sublimity of the unfulfilled, un-communicated love between Lily and Selden. In fact, just as the high romantics, also in response to the reifying pressure of the modern world, sacralised concepts such as the imagination, beauty, or love itself, Wharton carefully presents Lily and Selden's love as sublime and postulates this kind of sublimity as a consoling source of transcendence and meaning in the absurd, deterministic world pictured by the novel. With this, the novel achieves an equilibrium of pathos that is aesthetically satisfying and no doubt sought by its author. Only after Lily's tragic death does Selden realize her saintly nature and the precious character of their relationship. Something from which, by the side of Lily's dead body, he obviously draws consolation:

But at least he had loved her-had been willing to stake his future on his faith in her-and if the moment had been fated to pass from them before they could seize it, he saw now that, for both, it had been saved out of the ruin of their lives It was this moment of love, this fleeting victory over themselves, which had kept them from atrophy and extinction; which, in her, had reached out to him in every 
struggle against the influence of their surroundings, and in him, had kept alive the faith that now drew him penitent and reconciled to her side. (347)

Of course, here Selden is retrospectively constructing his relationship with Lily, in blatant contradiction with his previous withdrawal. But this is of little importance for the reader now, under the emotional force of Lily's death. The pathos of tragedy works to smooth out the contradictions that run through The House of Mirth. Now, at the end of the novel, the previously perceptible tension between Wharton's awareness of the forces of commodification and dissemination of the self and her desire to assert a centred kind of individuality abates. The novel shows that there is a true inner self that can resist the social forces of alienation, and there exists a kind of sublimity - in renunciation, in unfulfilled love - that can bestow meaning on a meaningless world. This conclusion is one that may help its readers through a world not completely unlike the one the novel describes. This takes us back to some of the theoretical grounds of this article: as Jameson and Moretti argue in different but compatible ways, the novelistic genre plays a part in the adaptation of individuals to their milieu. With all its contradictions, the notion of subjectivity proposed by The House of Mirth is an ideological construction enabled by a particular social, cultural and economic environment and, at the same time, a sort of compensation for its more disturbing characteristics. The fact that Lily's predicament still resonates with contemporary readers would show that there are crucial aspects where our contemporary societies are not that different to those portrayed by the novel.

\section{References}

Armstrong, Nancy (2005). How Novels Think: The Limits of individualism 1719-1900. New York: Columbia University Press.

Austin, J.L. (1975). How to Do Things with Words. Cambridge, MA: Harvard U P.

Beck, Ulrich (1992). Risk Society: Towards a New Modernity. Translated by Mark Ritter. London, etc.: SAGE.

Benstock, Shari, ed. (1994). Edith Wharton's The House of Mirth. Boston/New York: Bedford/St. Martin's.

Benveniste, Emile (1974). Problèmes de linguistique générale. Paris : Gallimard.

Bourdieu, Pierre (1984). Distinction: A Social Critique of the Judgement of Taste. Translated by Richard Nice. Cambridge, MA: Harvard University Press.

Brooks, Peter (2000). Troubling Confessions: Speaking Guilt in Law and Literature. Chicago and London: The University of Chicago Press.

Derrida, Jacques (1981). Dissemination. Translated by Barbara Johnson. London: The Athlon Press.

Dimock, Wai Chee (2003). Debasing Exchange: Edith Wharton's The House of Mirth. In Singley, Carol J., ed., 63-84.

Esch, Deborah, ed. (2001). New Essays on The House of Mirth. Cambridge: Cambridge University Press.

Heidegger, Martin (1996). Being and Time. Translated by Joan Stambaugh. Albany: State University of New York Press.

Jameson, Fredric (2002 [1981]). The Political Unconscious: Narrative as a Socially Symbolic Act. London and New York: Routledge. 
Kant, Immanuel (1987). The Critique of Judgement. Translated by Werner S. Pluhar. Indianapolis: Hackett.

Lakoff, George, and Johnson, Mark (1980). Metaphors We Live by. Chicago and London: University of Chicago Press.

Lidoff, Joan (2003). Another Sleeping Beauty: Narcissism in The House of Mirth. In Singley, Carol J., ed., 184-207.

Marx, Karl and Engels, Friedrich (2010). The Communist Manifesto. London: Arcturus.

Moretti, Franco (1987). The Way of the World: The Bildungsroman in European Culture. Translated by Albert Sbragia. London and New York: Verso.

Norris, Margot (1994). Death by Speculation: Deconstructing The House of Mirth. In Benstock, Shari, ed., 431-446.

Nyquist, Mary (2001). Determining Influences: Resistance and Mentorship in The House of Mirth and the Anglo-American Realist Tradition. In Esch, Deborah, ed., 43-105.

Showalter, Elaine (2003). The Death of the Lady (Novelist): Wharton's The House of Mirth. In Singley, Carol J., ed., 39-62.

Singley, Carol J., ed. (2003). Edith Wharton's The House of Mirth: A Casebook. New York: Oxford University Press.

Wharton, Edith (1996). Four Novels: The House of Mirth, Ethan Frome, The Custom of the Country, The Age of Innocence. Edited by R.W.B. Lewis. New York: Library of America.

Wharton, Edith (2001). Collected Stories, 1891-1910. Edited by Maureen Howard. New York: Library of America.

Žižek, Slavoj (1989). The Sublime Object of Ideology. London: Verso. 